\title{
STUDI ANGKA BEBAS JENTIK (ABJ) DAN INDEKS OVITRAP DI PERUM PONDOK BARU PERMAI DESA BULAKREJO KABUPATEN SUKOHARJO
}

\author{
Tri Puji Kurniawan
}

Fakultas Kesehatan Masyarakat. Universitas Veteran Bangun Nusantara Sukoharjo. Jl. Letjend. Sujono Humardani No 1 Kampus Jombor, Sukoharjo 57521

Email : tripujisiip@gmail.com

\begin{abstract}
ABSTRAK
Penyakit DBD masih merupakan permasalahan serius di Provinsi Jawa Tengah, terbukti 35 kabupaten/kota sudah pernah terjangkit penyakit DBD. Data penderita DBD pada UPT Puskesmas Sukoharjo tahun 2014 Sebanyak 22 kasus dengan IR 0,08\% dan tahun 2015 sebanyak 26 kasus IR $0,05 \%$. Data tersebut yang paling tinggi kasusnya berada pada Desa Bulakrejo 18 kasus. Tujuan penelitian ini adalah untuk pemantauan jentik nyamuk dengan metode visual dan menganalisis Nilai ABJ di Perum Pondok Baru Permai Bulakrejo Sukoharjo. Penelitian ini bersifat Survey Analitik rancangan yang digunakan dengan survei Cross Sectional. Pengumpulan sampel dilakukan dengan cara memantau keberadaan jentik dan pemasangan ovitrap untuk mengetahui indeks ovitrap dan nilai ABJ pada 100 rumah di Perum Pondok Baru Permai Bulakrejo Sukoharjo kemudian dihitung untuk ABJ nya. Dengan indikator amannya 95\%. Hasil Kepadatan Jentik dengan cara pemantauan jentik metode visual nyamuk dengan perhitungan container index didapatkan hasil sebesar $15 \%$, Nilai Angka Bebas jentik sebesar $85 \%$ dan indeks ovitrap sebesar $100 \%$ di Perum Pondok Baru Permai Desa Bulakrejo Kabupaten Sukoharjo.
\end{abstract}

Kata Kunci: ABJ, Indeks Ovitrap dan DBD

\begin{abstract}
DHF is a serious problem in Central Java, 35 districts / cities been infected by dengue. DHF patients in health center Sukoharjo by 2014 there were 22 cases with IR $0.08 \%$ and in 2015 there were 26 cases with IR $0.05 \%$. The highest case was in the village of Bulakrejo 18 cases. The purpose of this study is to monitor mosquito larvae with visual methods and analyze the value free numbers larva in Perum pondok baru permai Bulakrejo Sukoharjo. This research is an Analytical Survey design is in use with a Cross Sectional Survey. Sample collection is done by monitoring the presence of larvae and installation ovitrap to know ovitrap index and value free numbers larva on 100 homes in perum pondok baru permai Bulakrejo Sukoharjo then calculated for its free numbers larva. safe indicator $95 \%$. Flick density results in a way of monitoring mosquito larvae visual method by container index calculation results obtained by $15 \%$,
\end{abstract}


Value free numbers larva $85 \%$ and $100 \%$ ovitrap index in Perum Pondok Baru Permai Bulakrejo Sukoharjo.

Keywords: free numbers larva, ovitrap index and Dengue haemoragic fever

\section{PENDAHULUAN}

Lingkungan yang bersih dan sehat identik dengan lingkungan yang jauh dari unsur kotor dan pengganggu lainnya. Pengganggu ini tidak hanya datang dari sampah yang berserakan atau tempat yang kumuh, akan tetapi lingkungan yang bersih juga harus jauh dari unsur hewan pengganggu, vektor, maupun hewan lain yang akan menambah kekumuhan tempat tersebut dan mengganggu kesehatan misalnya jentik nyamuk. Jentik nyamuk apabila tumbuh manjadi nyamuk dewasa jika menggigit manusia bisa menimbulkan penyakit, misalnya malaria yang disebabkan gigitan nyamuk (Aditama, 2009).

Departemen Kesehatan RI menyatakan bahwa sepanjang tahun 2014 terdapat kejadian demam berdarah dengue sebanyak 71.668 kasus di 34 provinsi di seluruh Indonesia. Jumlah kasus meninggal dari 71.668 sebanyak 641 orang $(\mathrm{CFR}=0,89)$. Pada tahun 2014, jumlah penderita DBD Provinsi Jawa Tengah mencapai 6.296 penderita (IR $=0,02 \%$ ), sedangkan bulan Januari 2015 , jumlah pasien sebanyak 8 orang dengan 3 orang meninggal dunia $(\mathrm{CFR}=37,5 \%)$. Data penyakit DBD di Kabupaten Sukoharjo mengalami peningkatan setiap tahunnya, data pada tahun 2012 menunjukkan bahwa Kabupaten Sukoharjo memiliki kasus DBD sebayak 13 kasus (IR=0,10\%), tahun 2013 memiliki 37 kasus ( $\mathrm{IR}=0,30 \%$ ) dan pada tahun 2014 sampai sekarang terdapat 43 kasus ( $I R=0,35 \%$ ). Kasus DBD di Kabupaten Sukoharjo selalu mengalami peningkatan dan kasus DBD masih tetap ada sampai tahun 2015 sebanyak 41 kasus $(\mathrm{IR}=0,33 \%)$ (Depkes, 2012).

Data penderita DBD pada UPT

Puskesmas Sukoharjo tahun 2014 Sebanyak 22 kasus dengan IR 0,08\% dan tahun 2015 sebanyak 26 kasus IR 0,05\%. Data tersebut yang paling tinggi kasusnya berada pada Desa Bulakrejo 18 kasus. Kejadian DBD tersebut ada kaitannya dengan perilaku masyarakat dalam PSNDBD.

Survei pendahuluan yang dilakukan oleh peneliti pada bulan November 2015, bahwa perilaku PSN (Pemberantasan Sarang Nyamuk) oleh mayarakat di Wilayah Kerja UPT Puskesmas Sukoharjo masih belum baik. Survei yang dilakukan melalui wawancara dengan warga, dapat diketahui bahwa dari 15 warga terdapat 13 warga $(86,7 \%)$ yang tidak melaksanakan PSN DBD sehingga kepadatan nyamuk dan jentik menjadi besar dengan alasan malas melaksanakan PSN. Masyarakat yang malas tersebut umumnya disebabkan karena sibuk dengan pekerjaan di sawah maupun pekerjaan lain yang mampu menghasilkan uang daripada harus memperhatikan kondisi rumah mereka. Padahal jika ditinjau dari segi kesehatan kondisi rumah lebih penting bagi kelangsungan hidup mereka. Pemberantasan Sarang Nyamuk DBD yang umunya belum dilaksanakan dengan baik oleh warga, diantaranya tidak menutup penampungan air, menguras bak mandi lebih dari satu minggu sekali, tidak mengubur barang bekas dan hampir semua warga menggantung pakaian di dalam rumah.

Penelitian ini bertujuan untuk mengetahui faktor risiko keberadaan 
jentik nilai $\mathrm{ABJ}$ dan ovitrap indeks yang menjadi penyebab Kejadian Demam Berdarah Dengue pada masyarakat di Perum Pondok Baru Permai Desa Bulakrejo Kabupaten Sukoharjo

\section{METODE PENELITIAN}

Penelitian ini bersifat Survey Analitik dengan rancangan survei Cross Sectional. Populasi dalam penelitian ini adalah seluruh rumah Perum Pondok Baru Permai Desa Bulakrejo Kabupaten Sukoharjo. Teknik pengambilan sampel dengan cara total sampling. Jadi setiap rumah dipantau untuk keberadaan jentik dan telur nyamuknya. Jumlah sampel yang diperlukan dalam penelitian ini sebanyak 100 rumah.

Jenis data pada penelitian ini berupa data kuantitatif yang berupa data keberadaan jentik, ABJ dan ovitrap indeks. Sumber data dalam penelitian ini adalah data primer yang diperoleh dari hasil pemantauan jentik dan telur nyamuk secara visual perhitungan kepadatan jentik, ABJ dan indeks ovitrap. Identifikasi dan perhitungan indeks pinjal dilakukan di Laboratorium Kesehatan Masyarakat FKM Univet Bantara Sukoharjo. Pengumpulan data dilakukan dengan cara observasi, survei, dan perhitungan $\mathrm{ABJ}$ dan indeks ovitrap.

\section{HASIL DAN PEMBAHASAN Gambaran Umum}

Penelitian ini dilakukan di Perum Pondok Baru Permai Desa Bulakrejo Kabupaten Sukoharjo. Perum Pondok Baru Permai Desa Bulakrejo terletak di tengah atau pusat kota Sukoharjo. yang terdiri dari 100 unit rumah denga tipe yang berbeda beda. Dari 100 rumah yang dihuni oleh warga terdapat 30 rumah.

Adapun secara geografis perum ini terletak di tengah persawahan warga dengan karakter perkerjaan atau mata pencaharian warga perum yang beraneka ragam.

\section{Kepadatan Jentik dengan cara pemantauan jentik metode visual nyamuk di Perum Pondok Baru Permai Desa Bulakrejo Kabupaten Sukoharjo}

Persiapan yang dilakukan berupa survei lokasi dan kebutuhan kontainer. Lokasi yang digunakan untuk pengamatan adalah area Perumahan Pondok Baru Permai. Kontainer yang digunakan di kamar mandi adalah berbahan porselen dan bak plastik.

Container Indeks : Jumlah kontainer positif jentik

$$
\begin{aligned}
& \text { Jumlah Kontainer yang di periksa } \\
& : \frac{15}{100} \\
& : 0,15
\end{aligned}
$$

Dari hasil pengamatan, dari 100 kontainer yang diamati di Perum terdapat 15 kontainer yang ada jentik nyamuk. Pada perhitungan container index didapatkan hasil sebesar $15 \%$. Itu artinya didapatkan Density Figure (DF) atau bisa dikatakan bahwa $\mathrm{DF}=5$. Sehingga kepadatan jentik nyamuk di Perum Pondok Baru Permai adalah dengan kepadatan sedang. Hasil dipengaruhi oleh perilaku warga masyarakat yang tidak rutin dalam membersihkan kamar mandi. Indeks kontainer merupakan presentase antara kontainer dimana ditemukan jentik terhadap seluruh kontainer yang diperiksa (Denny Riyono, 2010).

\section{Angka Bebas jentik di Perum Pondok Baru Permai Desa Bulakrejo Kabupaten Sukoharjo}


Angka Bebas Jentik : Jumlah bangunan yang ditemukan jentik x 100\% Jumlah Rumah yang diperiksa

$: \underline{85} \times 100 \%$

100

$: 85 \%$

Untuk mengetahui kepadatan vektor nyamuk pada suatu tempat, diperlukan survei yang meliputi suvei nyamuk, survei jentik, dan survei perangkap telur (ovitrap) (Taviv, 2009). Angka bebas jentik didapatkan hasil sebesar $85 \%$. Artinya, dari ke 15 rumah yang diperiksa tersebut masih terdapat jentik nyamuk. Indikator ABJ yang $95 \%$, di perum dinyatakan masih di bawah indikator yang mana merupakan faktor risiko untuk terjadinya persebaran penyakit DBD karena vektor nyamuk menjadi besar.

Jadi berdasarkan hasil diatas, kemungkinan di area Perum Pondok Baru Permai tersebut akan timbul penyakit seperti DBD, malaria, yellow fever, dan chikungunya adalah $15 \%$ berdasarkan pengamatan dan pengukuran diatas.

\section{Indeks ovitrap di Perum Pondok Baru Permai Desa Bulakrejo Kabupaten Sukoharjo}

Ovitrap Index = Jumlah jentik dari seluruh ovitrap $\times 100 \%$ Jumlah ovitrap yang digunakan

$$
=\frac{30}{30} \times 100 \%=100 \%
$$

Ovitrap ini akan ditempatkan baik di dalam atau di luar rumah yang gelap dan lembab karena nyamuk menyukai tempat-tempat tersebut untuk bertelur. Setelah satu minggu dilakukan pemeriksaan ada/tidaknya telur di paddel (food and environmental hygiene departement, 2014).

Persiapan yang dilakukan pertama kali adalah mencari referensi pembuatan ovitrap. Setelah itu, membeli alat dan bahan yang dibutuhkan dan kemudian

membuat ovitrap sebanyak 30 buah. Ovitrap yang sudah jadi diletakkan di 30 titik yaitu kamar mandi dan got saluran air di Perum Pondok Baru Permai Bulakrejo Sukoharjo.

Berdasarkan dari hasil perhitungan didapatkan indeks ovitrap sebesar $100 \%$. Untuk mengetahui interpretasi dari hasil yang didapatkan dapat dibandingkan dengan klasifikasi indeks ovitrap pada Tabel 1.

Tabel 1. Klasifikasi Ovitrap Index

\begin{tabular}{|c|c|l|}
\hline Klasifikasi & Ovitrap Index & \multicolumn{1}{c|}{ Tindakan yang dilaksanakan } \\
\hline Tingkat 1 & $<5 \%$ & $\begin{array}{l}\text { Pengawasan dengan cermat kondisi kebersihan lingkungan untuk } \\
\text { mencegah tempat perindukan nyamuk } \\
\text { Pemeriksaan mingguan untuk mengidentifikasi tempat perindukan } \\
\text { atau yang berpotensi dan meniadakan tempat yang mungkin } \\
\text { sebagai perindukan nyamuk }\end{array}$ \\
\hline Tingkat 2 & $>5 \%-20 \%$ & $\begin{array}{l}\text { Mengingatkan manajemen tempat umum untuk memeriksa secara } \\
\text { berkala (waktu tidak lebih tujuh } \\
\text { hari) dan menghilangkan tiap perindukan di sekitarnya. }\end{array}$ \\
\hline Tingkat 3 & $>20 \%-40 \%$ & $\begin{array}{l}\text { Kegiatan meniadakan tempat perindukan atau yang berpotensi lebih } \\
\text { ditingkatkan. }\end{array}$ \\
\hline Tingkat 4 & $>40 \%$ & $\begin{array}{l}\text { Memberikan kewenangan kepada perusahaan pest control untuk } \\
\text { mengatasi permasalahan nyamuk. Tindakan larvasida atau stadium } \\
\text { dewasa dapat diterapkan. }\end{array}$ \\
\hline
\end{tabular}

Sumber: http://www.fehd.gov.hk, 2014 
Indeks ovitrap $100 \%$ termasuk ke dalam tingkat 4 , artinya daerah tersebut termasuk rawan timbul penyakit DBD dan penularan penyakit kaki gajah. Karena pada area bangunan tersebut banyak ditemukan jentik jenis Aedes aegepty dan Culex. Pencegahan yang perlu dilakukan pengelolaan lingkungan antara lain :

a. Tutup wadah yang berpotensi tergenang air.

b. Tutup rapat tempat penampungan air bersih.

c. Rajin menguras tempat penampungan air bersih.

d. Penggunaan larvasida jika memang dibutuhkan.

\section{KESIMPULAN}

Berdasarkan hasil penelitian dapat disimpulkan sebagai berikut:

a. Kepadatan Jentik dengan cara pemantauan jentik metode visual nyamuk dengan perhitungan container index didapatkan hasil sebesar 15\% di Perum Pondok Baru Permai Desa Bulakrejo Kabupaten Sukoharjo

b. Nilai Angka Bebas jentik sebesar 85\% di Perum Pondok Baru Permai Desa Bulakrejo Kabupaten Sukoharjo

c. Indeks ovitrap sebesar $100 \%$ di Perum Pondok Baru Permai Desa Bulakrejo Kabupaten Sukoharjo

\section{DAFTAR PUSTAKA}

Aditama, T. Y., 2009, Standar Operasional Prosedur Pengendalian Resiko Lingkungan. Dirjen Pengendalian Penyakit dan Penyehatan Lingkungan Kementerian Kesehatan Republik Indonesia, http://www.slideshare.net/masripsarumpaet1/sop-prl-kkp, diakses tanggal 04 Mei 2014.

Depkes, 2012, Pedoman Pengendalian Deman Chikungunya Edisi 2, Dirjen Pengendalian Penyakit dan Penyehatan Lingkungan Kementerian Kesehatan Republik Indonesia, http://pppl.depkes.go.id/_asset/_download/bk\%20cikungunya\%20edited_27 10_12ok.pdf, diakses tanggal 04 Mei 2014.

Denny Riyono., 2010, Nyamuk Sebagai Vektor Penyakit ( Malaria, demam Berdarah, Demam Tulang, Kaki Gajah ) di Indonesia. http://www.docstoc.com/docs/112724650/Nyamuk-sebagaiVektorPenyakit, diakses tanggal 9 Maret 2014.

Food and Environmental Hygiene Departement, 2014, Dengue Fever Ovitrap Index Update, http://www.fehd.gov.hk/english/safefood/dengue_fever/ovitrap_index.html, diakses tanggal 04 Mei 2014.

Taviv, Yulian., 2009, Survei Jentik Tersangka Vektor Chikungunya di Desa Batumarta Unit 2 Kecamatan Lubuk Raja Kabupaten Ogan Komering Ulu Tahun 2009, Loka Litbang P2B2 Baturaja, <http://ejournal.litbang.depkes.go.id/index.php/spirakel/article/download/ 1241/646>. 